\title{
The Cellulolytic Bacteria $R$. albus for Improving the Efficiency of Microbial Fuel Cell
}

\author{
Rebecca Chung1, Diane J. Moon², Yoo Na Chang3, David S. Chung4, Taekwon Kong5, \\ Justin Kim6 \\ ${ }^{1}$ Centreville High School, Clifton, VA, USA \\ ${ }^{2}$ The Gwinnett School of Mathematics, Science, and Technology, Lawrenceville, GA, USA \\ ${ }^{3}$ Korean Minjok Leadership Academy, Gangwon-do, Korea \\ ${ }^{4}$ School of Arts and Sciences, Brown University, Providence, RI, USA \\ ${ }^{5}$ Department of Chemistry, College of Arts \& Sciences, Washington University, St. Louis, MO, USA \\ ${ }^{6}$ School of Art \& Sciences, University of Pennsylvania, Philadelphia, PA, USA \\ Email: paulschung08@gmail.com
}

How to cite this paper: Chung, R., Moon, D.J., Chang, Y.N., Chung, D.S., Kong, T. and Kim, J. (2018) The Cellulolytic Bacteria $R$. albus for Improving the Efficiency of Microbial Fuel Cell. Journal of Sustainable Bioenergy Systems, 8, 36-46.

https://doi.org/10.4236/jsbs.2018.82003

Received: February 22, 2018

Accepted: June 25, 2018

Published: June 28, 2018

Copyright $\odot 2018$ by authors and Scientific Research Publishing Inc. This work is licensed under the Creative Commons Attribution International License (CC BY 4.0).

http://creativecommons.org/licenses/by/4.0/

(c) (i) Open Access

\begin{abstract}
The current study has been undertaken to examine the beneficial effect in the power output of a microbial fuel cell (MFC) by adding cellulolytic bacteria Ruminococcus albus ( $R$. albus) into the anodic chamber. Mediator-less H-type MFCs were set up where the anode chamber contained anaerobic digester microorganisms as inocula on finely ground pine tree (Avicel) at $2 \%$ $(\mathrm{w} / \mathrm{v})$ and the cathode chamber of $10 \mathrm{mM}$ phosphate buffered saline conductive solution, both separated by a cation exchange membrane. The functioning of the MFCs for generation of electrical power and the amounts of gaseous byproducts was monitored over a 9-day period. The addition of cellulolytic bacteria caused an increase of average power density from $7.9 \mathrm{~m} \mathrm{~W} / \mathrm{m}^{2}$ to 19.5 $\mathrm{m} \mathrm{W} / \mathrm{m}^{2}$, about $245 \%$ increase over a 9 -day period. For both groups of MFCs; with $R$. albus and the control, the head space gases collected were methane and $\mathrm{CO}_{2}$. While the methane: $\mathrm{CO}_{2}$ ratios were found unchanged at 1.7:1 throughout the 9 days of operation, the total gas production increased from $248 \mathrm{~mL}$ to $319 \mathrm{~mL}$ due to the presence of $R$. albus addition. This study confirms that whereas the biocatalytic activity of anode microbial population determines the energy production, the addition of external cellulolytic bacteria into anode microbial population can improve and extend the biomass utilization.
\end{abstract}

\section{Keywords}

Microbial Fuel Cell (MFC), Cellulolytic Bacteria, Microorganism, R. albus 


\section{Introduction}

All over the world, fossil fuels such as petroleum, coal, and natural gas have served as the main energy resources for industrialization and economic growth for the past century [1], and represent $79.4 \%$ of the global primary energy use in 2001 [2]. While 418 exajoules $\left(10^{18} \mathrm{~J}\right)$ of energy was used and total sales of energy carriers amounted to an astounding US \$2 trillion world-wide in 2001, more than 2 billion people still cannot access affordable energy services [2]. Fossil fuel reserves may run out in just over 100 years [3]. Not to disregard, the use of fossil fuels negatively impacts the environment due to the emission of greenhouse gases including $\mathrm{CO}_{2}$, methane, and $\mathrm{CO}$, which cause global warming and pollution [4]. For these reasons, greater efforts are currently being undertaken worldwide to develop technologies that generate clean, sustainable energy sources that would replace and/or displace fossil fuels [5].

As one of the most abundant renewable resources, cellulosic biomass is particularly attractive because of its relatively low cost, plentiful supply [6] [7], and neutral carbon balance [8]. The U.S. Departments of Agriculture and Energy estimated the annual availability at 1.3 billion dry tons of biomass feedstock in the United States, which could replace $30 \%$ or more of the country's present petroleum consumption. It should be noted that cellulose is a significant component in the annual production of 250 million tons municipal solid wastes and 40 billion cubic meters wastewater [9]. Depending on the end-use application, cellulosic biomass could be converted to a variety of energy carriers such as ethanol [10], biodiesel [11], and hydrogen [12], as well as to electricity indirectly derived from cellulose by coupling cellulolytic, fermentative hydrogen production with the catalytic oxidation of hydrogen at a fuel cell anode [8].

Representing an alternative method of renewable energy recovery, the direct conversion of biomass including organic waste to electricity using a microbial fuel cell (MFC) or to hydrogen, using a microbial electrolysis cell (MEC) offers the potential of clean and distributed energy production [13]. Using electrochemically active microorganisms as biocatalysts, MFCs are bioelectrochemical reactors that convert organic materials directly into the electricity [13], and they are endowed with tremendous electron donor versatility. These include simple substrates such as glucose, acetate, and lactate [14] [15] [16] [17]; complex substrates such as municipal and industrial wastewaters [18] [19]; even steam-exploded corn stover hydrolysate [20] and finally, cellulose [1] [21] [22] [23] [24].

Many types of bacteria have been found to be electrochemically active however, none of them is known to show a cellulolytic activity to generate electrons directly, and most of them require hydrolysis products of cellulose as electron donors [14] [25] [26] [27]. Exogenous redox mediators for electron transfer to the electrode are not desirable because these electron shuttles are toxic and need to be replenished periodically. Due to the lack of an isolated microbe that can both hydrolyze cellulose and reduce solid extracellular electron acceptors, one strategy to directly produce electricity from cellulosic biomass would involve a 
synergistic consortium of polymer-degrading fermentative microorganisms and fermentation products by utilizing electrochemically active microorganisms. Microorganisms that have been tested as biocatalysts for use in MFCs include pure or defined co-culture of obligate and facultative anaerobic bacteria [1] [14] [22] [25], and mixed cultures from sea floor sediments [28] [29], municipal and industrial wastewater or anaerobic digester [30] [31] [32], soil [1] [33] and rumen microbiota [24].

The rumen microbiota contains both strict and facultative anaerobes, which effectively hydrolyze cellulose and conserve energy via anaerobic respiration or fermentation, have been used for enhancing anodic efficiency [24] [34]. Microorganisms in anaerobic digesters have shown electrochemical activities that successfully transferred electrons to anode in MFCs [35] [36] [37] [38] [39]. Including rumen contents or anaerobic digester contents, studies have been carried out with mixed microorganism as anolyte inoculum to investigate single resource of cultures as both cellulolytic and electron transfer microorganisms. Studies of biomass degradation and electron transfer to electrode are conducted by different microorganisms, where more than one resource of mixed microorganisms may be selected for each symbiotic and synergetic role in MFCs.

We hypothesized that the combination of strong cellulolytic microorganisms and well established electrochemically active microorganisms in anode chamber would ferment cellulosic biomass more efficiently, and subsequently generate more electricity in MFCs. In the current study, we established MFCs consisting of anaerobic digester microorganisms as anolyte and cellulose as electron donor, and further by supplementing with culture of cellulolytic rumen bacteria, $R$ albus [40], and investigated whether this would result in an increase of cellulose fermentation and whether the higher cellulose degradation would directly translate to an enhanced electricity generation in MFC.

\section{Materials \& Methods}

\subsection{Microorganisms and Culture Media}

The anaerobic digester fluid used as MFC anode chamber inoculums was collected from a dairy farm with the following treatment: Under flushing of $\mathrm{CO}_{2}$ gas through heated copper column, the fluid was filtered through 4 layers of cheesecloth and glass wool, and then bubbled with $\mathrm{CO}_{2}$ gas until being transferred to MFCs.

A stock culture of $R$. albus stain 7 ( ATCC $^{\circledR} 27210^{\mathrm{mm}}$ ) was transferred to an anaerobically prepared medium containing cellobiose, $1 \mathrm{~g} ; \mathrm{KH}_{2} \mathrm{PO}_{4}, 0.48 \mathrm{~g}$; $\mathrm{K}_{2} \mathrm{HPO}_{4}, 0.48 \mathrm{~g} ;\left(\mathrm{NH}_{4}\right)_{2} \mathrm{SO}_{4}, 0.48 \mathrm{~g} ; \mathrm{NaCl}, 0.96$ g; Trypticase, 5.0 g; yeast extract, $1.0 \mathrm{~g}$; isobutyric acid, isovaleric acid, and DL-2-methylbutyric acid, $0.1 \mathrm{ml}$ of each; cysteine hydrochloride, $0.5 \mathrm{~g}$; $\mathrm{CaCl}_{2} \cdot 2 \mathrm{H}_{2} \mathrm{O}, 0.13 \mathrm{~g}$; $\mathrm{MgSO}_{4} \cdot 7 \mathrm{H}_{2} \mathrm{O}, 0.2 \mathrm{~g}$; $\mathrm{Na}_{2} \mathrm{CO}_{3}, 4.0 \mathrm{~g}$; sodium fumarate, $1.0 \mathrm{~g}$, and resazurin, $1.0 \mathrm{mg}$ per $1 \mathrm{~L}$ of medium volume with distilled deionized (dd) $\mathrm{H}_{2} \mathrm{O}$. After $48 \mathrm{~h}$ incubation at $39^{\circ} \mathrm{C}$, an aliquot of $0.5 \mathrm{~mL}$ culture was transferred to $10 \mathrm{~mL}$ of the same fresh medium and 
incubated for 48 hat $39^{\circ} \mathrm{C}$. Thereafter, $1 \mathrm{~mL}$ of the subculture was inoculated to anode chamber of the MFCs.

Phosphate buffered saline (PBS) was prepared by dissolving $\mathrm{NaCl}, 8 \mathrm{~g}$; $\mathrm{KCl}$,

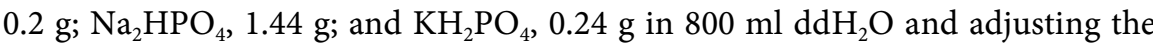
$\mathrm{pH}$ to 7.5 and volume to $1 \mathrm{~L}$ with $\mathrm{ddH}_{2} \mathrm{O}$. PBS was autoclaved at $121^{\circ} \mathrm{C}$ for 30 min and stored at room temperature until being transferred to MFCs.

\subsection{Microbial Fuel Cells}

Mediator-less two chamber H-type microbial fuel cell was constructed using two $125 \mathrm{~mL}$-volume glass jars, as anode and cathode chambers, adjoined at branched tubular bridge, and a proton exchange membrane (CMI-7000S, Membranes International Inc., NJ) clamped between tubular bridges, separating them.

A $2 \mathrm{~g}$ cellulose (Avicel PH-101, 11363 Sigma-Aldrich, MO) and $100 \mathrm{~mL}$ of anaerobic digester fluid collected from a dairy farm were transferred to the anode chamber and suspended by agitation. Graphite stick $\left(12 \mathrm{~cm}^{2}\right)$ connected with copper wire was placed in the middle of anode chamber and the chamber was closed with butyl rubber stopper. A $100 \mathrm{~mL}$ PBS was transferred to the cathode chamber and a graphite stick $\left(12 \mathrm{~cm}^{2}\right)$ connected with copper wire was placed in the middle. Rubber stopper was used to cap the cathode chamber but was made open to air through a tubing on the stopper. Anode and cathode were connected externally with a copper wire and a load resistor (300 ohm). MFCs were operated in a water bath at $39^{\circ} \mathrm{C}$ for $9 \mathrm{~d}$ prior to the treatment inoculation.

After $9 \mathrm{~d}$ of MFC operation, before treatment inoculation, current density for MFCs was measured to be $176 \pm 6.5 \mathrm{~mA} / \mathrm{m}^{2}$. One $\mathrm{mL}$ of $R$. albus, grown in a cellobiose medium for $48 \mathrm{~h}$, was inoculated into anode chambers of the treatment group MFCs, and $1 \mathrm{~mL}$ of pure cellobiose medium was added to anode chambers of the control group MFCs. Anode chamber stoppers were open to the atmosphere to equalize pressure and remove the headspace gas. $2 \mathrm{~L}$-volume balloons were connected to each anode chamber to collect gases produced.

\subsection{Measurements and Calculation}

MFC voltage across an external resistor, end point potential, and current were measured daily using a multimeter from $\mathrm{d} 0$ to $\mathrm{d} 9$. The power density was calculated according to $P=\mathrm{I} \times \mathrm{V} / \mathrm{A}$, with $\mathrm{I}=$ current, $\mathrm{V}=$ voltage, $\mathrm{R}=$ external resistance, and $\mathrm{A}\left(\mathrm{m}^{2}\right)=$ the projected area of the cathode.

On d9, balloons connected to anode chambers were collected and total volumes of fermentation gas produced were measured. $\mathrm{CO}_{2}$ and methane profile was analyzed using an Agilent gas chromatograph equipped with a thermal conductivity detector and a stainless steel packed (12390-U, Supelco, Sigma-Aldrich, MO).

\subsection{Statistical Analyses}

Effects of $R$. albus addition to anaerobic digester fluid in anode chamber of MFC 
on electricity generation, fermentation gas production and gas composition were analyzed using the one-way ANOVA procedure of JPM 12.2.0 (SAS Institute Inc., NC) and when the effect was significant $(P<0.05)$, treatment means were separated using students' t-test. Significance was declared at $P<0.05$.

\section{Results and Discussion}

\subsection{Voltages}

MFCs consisting of $2 \% \mathrm{w} / \mathrm{v}$ Avicel and $100 \mathrm{~mL}$ of anaerobic digester fluid were constructed and stabilized for $9 \mathrm{~d}$ and power density was measured to be $11.2 \pm$ $0.86 \mathrm{~mW} / \mathrm{m}^{2}$ prior to applying the treatments. It was noted in control group that the voltage across resistor and endpoint potential (open circuit voltage) showed a decrease $(P<0.05)$ on $\mathrm{d} 2$ and fluctuated thereafter with time courses (Table 1 ). The control group as received had $1 \% \mathrm{v} / \mathrm{v}$ of pure medium containing $0.1 \%$ cellobiose without $R$. albus, such that it was assumed that a slightly higher voltage on $\mathrm{d} 0$ and $\mathrm{d} 1$ (compared to the rest of operation period) might be induced by the spike of $0.001 \%$ cellobiose in the final volume of anolyte.

The Voltage across resistor and endpoint potential in the presence of $R$. albus group increased gradually after $3 \mathrm{~d}$ and then reached the highest at $\mathrm{d} 8$ (Table 1 ). $R$. albus MFCs had induced a greater $(P<0.05)$ voltage across resistor and endpoint potential than control MFCs after $\mathrm{d} 2$ except on $\mathrm{d} 4$ for open circuit voltage (Table 1).

\subsection{Gases Composition}

Supplementation of $R$. albus to anaerobic digester fluid increased overall gas

Table 1. Closed circuit voltage across $300 \mathrm{ohms}$ resistor and terminal.

\begin{tabular}{|c|c|c|c|c|c|c|c|c|}
\hline \multirow[b]{2}{*}{ Day } & \multicolumn{4}{|c|}{ Voltage across resistor (300 ohms), $\mathrm{mV}$} & \multicolumn{4}{|c|}{ Open circuit voltage, $\mathrm{mV}$} \\
\hline & Control & R. albus & SEM $^{1}$ & $\mathrm{P}^{2}$ & Control & R. albus & SEM $^{1}$ & $\mathrm{P}^{2}$ \\
\hline 0 & $64.0^{\mathrm{a}}$ & $60.0^{\mathrm{d}}$ & 2.24 & 0.3333 & $206.0^{\mathrm{a}}$ & $185.5^{\mathrm{d}}$ & 10.25 & 0.2930 \\
\hline 1 & $61.0^{\mathrm{ab}}$ & $65.0^{\mathrm{d}}$ & 2.55 & 0.3828 & $183.0^{\mathrm{ab}}$ & $190.0^{\mathrm{d}}$ & 7.78 & 0.5897 \\
\hline 2 & $50.0^{\text {cde }}$ & $69.5^{\mathrm{d}}$ & 2.85 & 0.0402 & $152.0^{\mathrm{cd}}$ & $219.0^{\mathrm{cd}}$ & 6.52 & 0.0184 \\
\hline 3 & $57.5^{\mathrm{abc}}$ & $80.5^{\mathrm{c}}$ & 2.69 & 0.0263 & $182.5^{\mathrm{b}}$ & $236.0^{\mathrm{bc}}$ & 7.56 & 0.0377 \\
\hline 4 & $53.0^{\mathrm{bcd}}$ & $86.5^{\mathrm{bc}}$ & 3.48 & 0.0209 & $163.5^{\mathrm{bc}}$ & $262.5^{\mathrm{ab}}$ & 17.87 & 0.0594 \\
\hline 5 & $49.0^{\mathrm{de}}$ & $93.0^{\mathrm{ab}}$ & 1.58 & 0.0026 & $144.0^{\mathrm{cd}}$ & $268.5^{\mathrm{ab}}$ & 2.85 & 0.0010 \\
\hline 6 & $50.5^{\text {cde }}$ & $93.0^{\mathrm{ab}}$ & 4.26 & 0.0195 & $153.5^{\mathrm{cd}}$ & $287.5^{\mathrm{a}}$ & 11.93 & 0.0155 \\
\hline 7 & $49.0^{\mathrm{de}}$ & $89.5^{\mathrm{bc}}$ & 2.26 & 0.0062 & $155.5^{\mathrm{cd}}$ & $265.5^{\mathrm{ab}}$ & 4.27 & 0.0030 \\
\hline 8 & $44.5^{\mathrm{e}}$ & $100.5^{\mathrm{a}}$ & 2.69 & 0.0046 & $133.0^{\mathrm{d}}$ & $295.5^{\mathrm{a}}$ & 5.06 & 0.0019 \\
\hline 9 & $49.5^{\text {cde }}$ & $90.0^{\mathrm{bc}}$ & 3.02 & 0.0109 & $150.0^{\mathrm{cd}}$ & $272.0^{\mathrm{a}}$ & 8.28 & 0.0091 \\
\hline SEM $^{1}$ & 2.60 & 3.29 & & & 7.31 & 10.77 & & \\
\hline $\mathrm{P}^{2}$ & 0.0028 & $<0.0001$ & & & 0.0010 & 0.0002 & & \\
\hline
\end{tabular}

${ }^{\text {abcde }}$ Means with different superscripts differ, $P<0.05$. ${ }^{1}$ Standard error of means. ${ }^{2} P$-value; probabilities that treatments or day effects are not significant. 
production, but did not change the gas composition (Figure 1). The total gas produced in anode chambers for $9 \mathrm{~d}$ after treatments amounted to 249 and 319 $\mathrm{mL}$ for control and $R$. albus MFCs, respectively (Figure 1). Gas production implies that the fermentation of electron donors occurred during the electricity generation, suggesting that fermentation was greater $(P=0.0351)$ in $R$. albus MFCs. While methane $(P=0.0548)$ and $\mathrm{CO}_{2}(P=0.0478)$ volumes were greater in $R$. ablus MFCs, the methane to $\mathrm{CO}_{2}$ ratios remained same for both MFCs $(P=$ 0.9381 ) with a ratio of $1.7: 1$.

The basic process for glucose in anode chamber is decomposition into $\mathrm{CO}_{2}$, proton and electron. The electrons and the protons move to cathode via the external electrical circuit and the exchange membrane, respectively, then reduce oxygen and produce water. Overall scheme in whole MFC is $\mathrm{C}_{6} \mathrm{H}_{12} \mathrm{O}_{6}+6 \mathrm{O}_{2} \rightarrow 6$ $\mathrm{CO}_{2}+6 \mathrm{H}_{2} \mathrm{O}+$ Electrical energy [41]. Both acetoclastic methanogenesis and hydrogeno-trophic methanogenesis require exogenous energy consumption [42] and reduce the flow of proton and electron to cathode, therefore methane production is regarded an inefficient process which detracts from electricity generation. In the current study, a similar pathway of cellulose fermentation can be deduced from the production rate of methane to $\mathrm{CO}_{2}$, which was not different between the $R$. albus and the control MFCs, and this implies that production of methane is a characteristic of anaerobic digester process.

\subsection{Power Density}

Power density (power normalized to the surface area of the electrodes) is a critical parameter to determine the bioelectrochemical performances of MFCs [43]. Power density in the control MFCs decreased $(P<0.05)$ on $\mathrm{d} 2$ and thereafter remained steady at between 5.5 and $7.8 \mathrm{~mW} / \mathrm{m}^{2}$ (Figure 2) while in $R$. albus MFCs, power density increased $(P<0.05)$ gradually after $\mathrm{d} 3$ registered in the range of 20.9 to $28.1 \mathrm{~mW} / \mathrm{m}^{2}$.When a sole rumen fluid was used as anolyte [24],

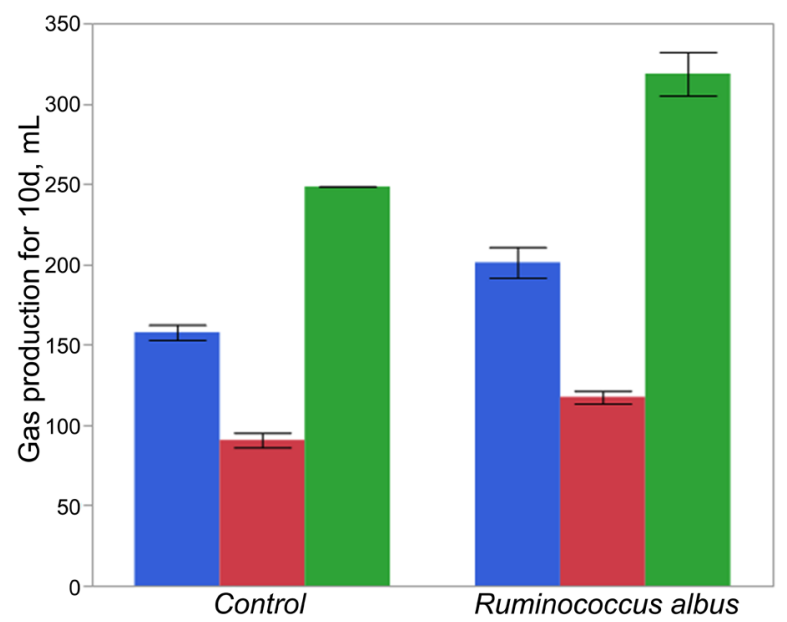

Figure 1. Components and total volume of gases produced in the anode chamber of microbial fuel cells for $10 \mathrm{~d}$ incubation. Methane, $\mathrm{CO}_{2}$, and total gas are presented as means of duplicate $(\mathrm{n}=2)$ with standard deviation. 


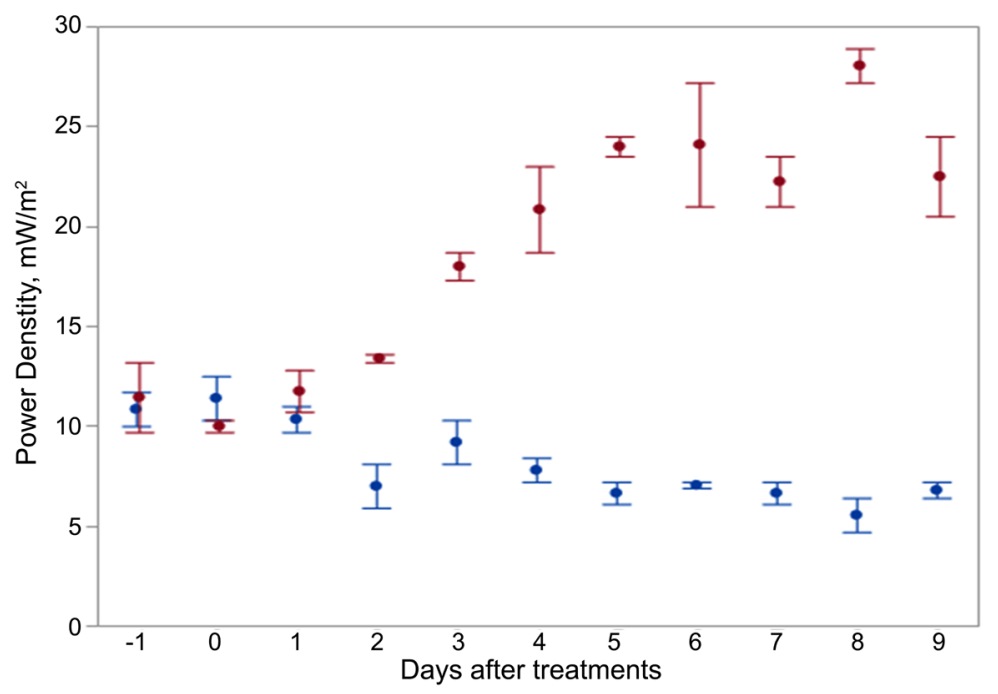

Figure 2. Power densities over 9 day incubation. Power densities are presented as means of duplicate $(\mathrm{n}=2)$ with standard error of mean for control and $R$. albus treatment.

55 and $26.7 \mathrm{~mW} / \mathrm{m}^{2}$ were reported as the highest and stable power density, respectively. However, in their setup, aerobic potassium ferricyanide solution (50 $\left.\mathrm{mM} \mathrm{K}_{3} \mathrm{Fe}(\mathrm{CN})_{6}\right)$ had been used as the catholyte to enhance oxygen reduction, so that the performance of our MFCs will not stand for a direct comparison. Besides, the performance can be restricted by the large internal resistance of H-type fuel cells with long distance between the anode and cathode and small surface area of the cation exchange membrane and hence, the power outputs need to be properly normalized [13].

Continuous power generation in control MFCs reflects the ongoing fermentation in anode chamber and the flow of electron and proton to cathode chamber. Gas production and power generation throughout the experimental period in the control MFC implies that anaerobic digester fluid might include not only electrochemically active but also cellulose degrading microorganisms. In accordance with the greater gas production, $R$. albus fermented and lysed cellulose more efficiently than the control, and provided more electron donors, which were available to electron transfer microorganisms on anode and resulted in greater power generation.

\section{Conclusions}

Because of its abundance and carbon neutral characteristics, cellulosic biomass is a desirable ingredient for biofuel production. In the current study, anaerobic digester fluid was employed as an anolyte in MFCs, which generated electricity from finely ground pinetree (cellulose). Addition of $R$. albus at $1 \% \mathrm{v} / \mathrm{v}$ into the anolyte increased gas production and power generation. These results suggest that addition of $R$. albus or other exogenous cellulolytic microorganisms to anaerobic digester MFC may degrade cellulosic biomass more rapidly such that generate electricity more efficiently. While this study draws a close similarity 
with that of Rismani-Yadzi et al. (2007), the difference in the composition of the catholyte is a distinct difference and demonstrates how the efficiency of the MFCs can be optimized vis-a-vis avoidance of toxic components such as potassium ferricyanide.

For a large scale development, although $R$. albus served as an important prototype, many other similar exogenous cellulolytic microorganisms should be screened in order to establish common structural characteristics and mechanistic pathway that facilitate efficient electrode processes.

\section{References}

[1] Hassan, S.H., Kim, Y.S. and Oh, S.E. (2012) Power Generation from Cellulose Using Mixed and Pure Cultures of Cellulose-Degrading Bacteria in a Microbial Fuel Cell. Enzyme and Microbial Technology, 51, 269-273. https://doi.org/10.1016/j.enzmictec.2012.07.008

[2] Goldemberg, J. and Johansson, T.B. (2004) World Energy Assessment Overview: 2004 Update. United Nations Development Programme. New York.

[3] Goldemberg, J. (2007) Ethanol for a Sustainable Energy Future. Science, 315, 808-810. https://doi.org/10.1126/science.1137013

[4] Saratale, G and Oh. S. (2011) Production of Thermotolerant and Alkalotolerant Cellulolytic Enzymes by Isolated Nocardiopsis sp. KNU. Biodegradation, 22, 905-919. https://doi.org/10.1007/s10532-010-9450-0

[5] Levin, D.B., Islam, R., Cicek, N. and Sparling, R. (2006) Hydrogen Production by Clostridium Thermocellum 27405 from Cellulosic Biomass Substrates. International Journal of Hydrogen Energy, 31, 1496-1503.

https://doi.org/10.1016/j.ijhydene.2006.06.015

[6] Lynd, L.R., Weimer, P.J., van Zyl, W.H. and Pretorius, I.S. (2002) Microbial Cellulose Utilization: Fundamentals and Biotechnology. Microbiology and Molecular Biology Reviews, 66, 506-577. https://doi.org/10.1128/MMBR.66.3.506-577.2002

[7] Schwarz, W.H. (2001) The Cellulosome and Cellulose Degradation by Anaerobic Bacteria. Applied Microbiology and Biotechnology, 56, 634-649.

https://doi.org/10.1007/s002530100710

[8] Niessen, J., Schröder, U., Harnisch, F. and Scholz, F. (2005) Gaining Electricity from in Situ Oxidation of Hydrogen Produced by Fermentative Cellulose Degradation. Letters in Applied Microbiology, 41, 286-290. https://doi.org/10.1111/j.1472-765X.2005.01742.x

[9] Perlack, R., Wright, L.L., Turhollow, A.F., Graham, A.F., Stokes, B.J. and Erbach, D.C. (2005) Biomass as Feedstock for a Bioenergy and Bioproducts Industry: The Technical Feasibility of a Billion-Ton Annual Supply. Oak Ridge National Laboratory, Oak Ridge, TN.

[10] Mielenz, J.R. (2001) Ethanol Production from Biomass: Technology and Commercialization Status. Current Opinion in Microbiology, 4, 324-329. https://doi.org/10.1016/S1369-5274(00)00211-3

[11] Powlson, D.S., Riche, A.B. and Shield, I. (2005) Biofuels and Other Approaches for Decreasing Fossil Fuel Emissions from Agriculture. Annals of Applied Biology, 146, 193-201. https://doi.org/10.1111/j.1744-7348.2005.040056.x

[12] Ni, M., Leung, D.Y.C., Leung, M.K.H. and Sumathy, K. (2006) An Overview of Hydrogen Production from Biomass. Fuel Processing Technology, 87, 461-472. https://doi.org/10.1016/j.fuproc.2005.11.003 
[13] Logan, B.E. and Regan, J.M. (2006) Microbial Fuel Cells-Challenges and Applications. Environmental Science \& Technology, 40, 5172-5180. https://doi.org/10.1021/es0627592

[14] Bond, D.R. and Lovley, D.R. (2003) Electricity Production by Geobacter Sulfureducens Attached to Electrodes. Applied and Environmental Microbiology, 69, 1548-1555. https://doi.org/10.1128/AEM.69.3.1548-1555.2003

[15] Liu, H., Cheng, S. and Logan, B.E. (2005) Production of Electricity from Acetate or Butyrate Using a Single-Chamber Microbial Fuel Cell. Environmental Science \& Technology, 39, 658-662. https://doi.org/10.1021/es048927c

[16] Liu, H., Grot, S. and Logan, B.E. (2005) Electrochemically Assisted Microbial Production of Hydrogen from Acetate. Environmental Science \& Technology, 39, 4317-4320. https://doi.org/10.1021/es050244p

[17] Park, D.H. and Zeikus, J.G. (2002) Impact of Electrode Composition on Electricity Generation in a Single-Compartment Fuel Cell Using Shewanella putrefaciens. Applied Microbiology and Biotechnology, 59, 58-61. https://doi.org/10.1007/s00253-002-0972-1

[18] Min, B., Kim, J., Oh, S., Regan, J.M. and Logan, B.E. (2005) Electricity Generation from Swine Wastewater Using Microbial Fuel Cells. Water Research, 39, 4961-4968. https://doi.org/10.1016/j.watres.2005.09.039

[19] Aelterman, P., Rabaey, K., Clauwaert, P. and Verstraete, W. (2006) Microbial Fuel Cells for Wastewater Treatment. Water Science \& Technology, 54, 9-15. https://doi.org/10.2166/wst.2006.702

[20] Zuo, Y., Maness, P.C. and Logan, B.E. (2006) Electricity Production from Steam-Exploded Corn Stover Biomass. Energy Fuel, 20, 1716-1721. https://doi.org/10.1021/ef0600331

[21] Ishii, S., Suzuki, S., Norden-Krichmar, T.M., Nealson, K.H., Sekiguchi, Y. and Gorby, Y.A. (2012) Functionally Stable and Phylogenetically Diverse Microbial Enrichments from Microbial Fuel Cells during Wastewater Treatment. PLoS ONE, 7, e30495. https://doi.org/10.1371/journal.pone.0030495

[22] Ren, Z., Ward, T.E. and Regan, J.M. (2007) Electricity Production from Cellulose in a Microbial Fuel Cell Using a Defined Binary Culture. Environmental Science and Technology, 41, 4781-4786. https://doi.org/10.1021/es070577h

[23] Rezaei, F., Richard, T.L., Brennan, R.A. and Logan, B.E. (2007) Substrate-Enhanced Microbial Fuel Cells for Improved Remote Power Generation from Sediment-Based Systems. Environmental Science and Technology, 41, 4053-4058. https://doi.org/10.1021/es070426e

[24] Rismani-Yazdi, H., Christy, A.D., Dehority, B.A., Morrison, M., Yu, Z. and Tuovinen, O.H. (2007) Electricity Generation from Cellulose by Rumen Microorganisms in Microbial Fuel Cells. Biotechnology and Bioengineering, 97, 1398-1407. https://doi.org/10.1002/bit.21366

[25] Chaudhuri, S.K. and Lovley, D.R. (2003) Electricity Generation by Direct Oxidation of Glucose in Mediatorless Microbial Fuel Cells. Nature Biotechnology, 21, 1229-1232. https://doi.org/10.1038/nbt867

[26] Desvaux, M., Guedon, E. and Petitdemange, H. (2000) Cellulose Catabolism by Clostridium cellulolyticum Growing in Batch Culture on Defined Medium. Applied and Environmental Microbiology, 66, 2461-2470. https://doi.org/10.1128/AEM.66.6.2461-2470.2000

[27] Lovley, D.R. (2006) Bug Juice: Harvesting Electricity with Microorganisms. Nature Reviews Microbiology, 4, 497-508. https://doi.org/10.1038/nrmicro1442 
[28] Bond, D.R., Holmes, D.E., Tender, L.M. and Lovley, D.R. (2002) Electrode-Reducing Microorganisms That Harvest Energy from Marine Sediments. Science, 295, 483-485. https://doi.org/10.1126/science.1066771

[29] Logan, B.E., Murano, C., Scott, K., Gray, N.D. and Head, I.M. (2005) Electricity Generation from Cysteine in a Microbial Fuel Cell. Water Research, 39, 942-952. https://doi.org/10.1016/j.watres.2004.11.019

[30] Higginsa, S.R., Lopeza, R.J., Pagalingb, E., Yanb, E. and Cooney, M.J. (2013) Towards a Hybrid Anaerobic Digester-Microbial Fuel Cell Integrated Energy Recovery System: An Overview of the Development of an Electrogenic Biofilm. Enzyme and Microbial Technology, 52, 344-351. https://doi.org/10.1016/j.enzmictec.2013.02.017

[31] Min, B. and Logan, B.E. (2004) Continuous Electricity Generation from Domestic Wastewater and Organic Substrates in a Flat Plate Microbial Fuel Cell. Environmental Science and Technology, 38, 5809-5814. https://doi.org/10.1021/es0491026

[32] Rabaey, K., Clauwaert, P., Aelterman, P. and Verstraete, W. (2005) Tubular Microbial Fuel Cells for Efficient Electricity Generation. Environmental Science \& Technology, 39, 8077-8082. https://doi.org/10.1021/es050986i

[33] Rubaba, O., Araki, Y., Yamamoto, S., Suzuki, K., Sakamoto, H., Matsuda, A. and Futamata, H. (2013) Electricity Producing Property and Bacterial Community Structure in Microbial Fuel Cells Equipped with Membrane Electrode Assembly. Journal of Bioscience and Bioengineering, 116, 106-113. https://doi.org/10.1016/j.jbiosc.2013.01.019

[34] Krause, D.O., Denman, S.E., Mackie, R.I. and Morrison, M. (2003) Opportunities to Improve Fiber Degradation in the Rumen: Microbiology, Ecology, and Genomics. FEMS Microbiology Reviews, 27, 663-693. https://doi.org/10.1016/S0168-6445(03)00072-X

[35] Fradler, K.R., Kim, J.R., Shipley, G., Massanet-Nicolau, J., Dinsdale, R.M., Guwy, A.J. and Premier, G.C. (2014) Operation of a Bioelectrochemical System as a Polishing Stage for the Effluent from a Two-Stage Biohydrogen and Biomethane Production Process. Biochemical Engineering Journal, 85, 125-131.

https://doi.org/10.1016/j.bej.2014.02.008

[36] Kim, T., An, J., Jang, J.K. and Chang, I.S. (2015) Coupling of Anaerobic Digester and Microbial Fuel Cell for COD Removal and Ammonia Recovery. Bioresource Technology, 195, 217-222. https://doi.org/10.1016/j.biortech.2015.06.009

[37] Premier, G.C., Kim, J.R., Massanet-Nicolau, J., Kyazze, G., Esteves, S.R.R., Penumathsa, B.K.V., Rodríguez, J., Maddy, J., Dinsdale, R.M. and Guwy, A.J. (2013) Integration of Biohydrogen, Biomethane and Bioelectrochemical Systems. Renewable Energy, 49, 188-192. https://doi.org/10.1016/j.renene.2012.01.035

[38] Weld, R.J. and Singh, R. (2011) Functional Stability of a Hybrid Anaerobic Digester/Microbial Fuel Cell System Treating Municipal Wastewater. Bioresource Technology, 102, 842-847. https://doi.org/10.1016/j.biortech.2010.09.002

[39] Xie, B., Liu, B., Yi, Y., Yang, L., Liang, D., Zhu, Y. and Liu, H. (2016) Microbiological Mechanism of the Improved Nitrogen and Phosphorus Removal by Embedding Microbial Fuel Cell in Anaerobic-Anoxic-Oxic Wastewater Treatment Process. Bioresource Technology, 207, 109-117. https://doi.org/10.1016/j.biortech.2016.01.090

[40] Suen, G., Stevenson, D.M., Bruce, D.C., Chertkov, O., Copeland, A., Cheng, J.F., Detter, C., Detter, J.C., Goodwin, L.A., Han, C.S., Hauser, L.J., Ivanova, N.N., Kyrpides, N.C., Land, M.L., Lapidus, A., Lucas, S., Ovchinnikova, G., Pitluck, S., Tapia, R., Woyke, T., Boyum, J., Mead, D. and Weimer, P.J. (2011) Complete Genome of the Cellulolytic Ruminal Bacterium Ruminococcus albus 7. Journal of Bacteriology, 
193, 5574-5575. https://doi.org/10.1128/JB.05621-11

[41] Pham, T.H., Rabaey, K., Aelterman, P., Clauwaert, P., De Schamphelaire, L., Boon, N. and Verstraete, W. (2006) Microbial Fuel Cells in Relation to Conventional Anaerobic Digestion Technology. Engineering in Life Sciences, 6, 285-292. https://doi.org/10.1002/elsc.200620121

[42] Kaur, A., Boghani, H.C., Michie, I., Dinsdale, R.M., Guwy, A.J. and Premier, G.C. (2014) Inhibition of Methane Production in Microbial Fuel Cells: Operating Strategies Which Select Electrogens over Methanogens. Bioresource Technology, 173, 75-81. https://doi.org/10.1016/j.biortech.2014.09.091

[43] Choi, S. (2015) Microscale Microbial Fuel Cells: Advances and Challenges. Biosensors Bioelectronics, 69, 8-25. https://doi.org/10.1016/j.bios.2015.02.021 